\title{
How Can Design Features and Other Factors Affect the Indoor Air Quality in Inpatient Rooms? Check-Lists for the Design Phase, Daily Procedures and Maintenance Activities for Reducing the Air Concentrations of Chemical Pollution
}

\author{
Marco Gola ${ }^{1, *(\mathbb{D}}$, Gaetano Settimo $^{2} \mathbb{D}$ and Stefano Capolongo ${ }^{1}$ \\ 1 Architecture, Built environment and Construction engineering Dept, Politecnico di Milano, \\ 20133 Milan, Italy; stefano.capolongo@polimi.it \\ 2 Environment and Health Dept, Istituto Superiore di Sanità, 00161 Rome, Italy; gaetano.settimo@iss.it \\ * Correspondence: marco.gola@polimi.it; Tel.: +39-02-2399-5140
}

Received: 20 April 2020; Accepted: 12 June 2020; Published: 15 June 2020

\begin{abstract}
Indoor Air Quality (IAQ) is one of main topics of Public Health on which international institutions and countries are taking action. With regards to healing architectures, several studies have reported data analysis and case studies to improve users' health (patients, and medical and administrative staffs), but there are not enough regarding volatile organic compounds (VOCs). Regarding chemical pollution of indoor air, the Scientific Community has highlighted that there are several factors that affect the IAQ, in particular the design and management, and energetic efficiency, of inpatient wards. Several stakeholders, from the designers to the managers, are responsible for the indoor air in healing environments. Supported by analysis of the State of the Art and the main factors that influence the heterogeneous scenario of inpatient wards, the paper presents three check-lists, designed for supporting the stakeholders during the design phase, or for the daily procedures and maintenance activities, for pre-assessment of factors that affect chemical pollution, and for the definition of strategies to be applied. In fact, in such environments IAQ assumes a particular meaning and importance, both for the vulnerability of the patients and for the long time spent by the sanitary staff. The multidisciplinary approach emphasizes the continuous need for interdisciplinary knowledge and skills aimed at finding solutions able to protect users' health status (including patients, workers and visitors), especially in the field of the indoor air issue.
\end{abstract}

Keywords: Indoor Air Quality (IAQ); check-lists; chemical pollution; inpatient room; design features; best practices; management and design strategies; health prevention

\section{Introduction: Indoor Air Quality in Hospital Settings}

Several stakeholders are responsible for health promotion in indoor environments, starting with the decision makers and the designers during the design process, to the managers and the users who will manage, work, use and live in the spaces [1].

Referring to the factors that affect the Indoor Environmental Quality (IEQ), the Indoor Air Quality (IAQ) is an issue already discussed in the 1980s [2-5], although only in recent years has it become a strategic issue for all the countries [6], as one of the goals of the United Nations' Sustainable Development.

Among the indoor environments, IAQ in "Architectures for Health" requires great attention for guaranteeing healthy indoor air and well-being, in particular for protecting patients and staff against Hospital Acquired Infections (HAIs) and occupational diseases [7,8]. In fact, it is well known that 
healthcare facilities are complex constructions, due to their dimensions, the high technologies for their functioning, the relevant presence of daily users, and their 24/7 operability [9].

Therefore, during the design process of hospital settings and their management, it is necessary to guarantee healthy spaces, starting with (a) the support of managers, medical and non-medical staff, maintainers and service providers, and (b) the design of hospital planners in relation to the layouts, the material selection, the rooms' dimension, the engineering plants, etc., which can highly affect the performances of the facility and its processes $[10,11]$. In fact, as Joseph and Rashid sustained, the Scientific Community has shown that healthcare design may directly affect safety in hospitals, and it probably indirectly influences safety by triggering adverse events that cause harm to users (both patients and staff) [12]. Moreover, it may also affect the safety in "Architectures for Health" to counteract risk factors and harmful events. Moreover, referring to Reiling et al., cognitive psychologists have stated that environment has a significant impact on safety and human performances [13]. As several authors highlighted, humans do not always behave clumsily and they do not always make mistakes, but their performances are highly influenced when they live and/or work in badly-conceived and -designed healing spaces [14-16].

In general, the IAQ within hospitals is a complex and dynamic system, in which physical factors, and biological and chemical contaminants generated in indoor environments, as well as those in the outdoor air that come into the building via natural ventilation (i.e., through manual window opening) and, primarily, mechanical ventilation (i.e., Heating, Ventilation and Air Conditioning systems; HVAC) play a role. The quality of the management and maintenance of engineering plants [15], the cleaning and disinfection activities, and the quality assessment plans are also all relevant [15,17]. It is well-known that some concentrations of outdoor pollutants (i.e., VOCs, benzene, formaldehyde, etc.) are lower than indoor ones, because of the internal sources, including HVAC systems, building and finishing materials, hospital staff, and medical activities [18].

Regarding the chemical composition of indoor spaces, there may be threats to the air quality from a range of indoor and outdoor sources [19-28]. Indoor sources include building and finishing materials, furniture, cleaning activities and products, use of specific chemical agents and disinfectants, quality of air ventilation and health education management protocols [29]. Humans are also considered a cause of chemical emissions [30].

Currently in the European Legislation, VOC concentrations and IAQ for generic indoor environments are limited via acts and norms in some countries, as Settimo and D'Alessandro [1] investigated, and currently many suggestions are being made for low and medium care hospital settings, excluding surgery blocks, laboratories, etc., as Settimo [31] highlighted.

Nowadays, for assessing chemical pollution, it is necessary to monitor activity, but this is not always possible to set it up immediately, and data analysis requires a long time. Therefore, the aim of the paper is to give rise to three check-lists for reducing chemical pollution in inpatient wards, for supporting designers, hospital planners, medical directors and managers, to be applied during the design phase, and for the application of daily procedures and maintenance activities in the defining of strategies for healthy performances. The focuses of the check-lists are related, referring to the current trends in hospital design, and to facilities with mechanical ventilation and/or mixed systems (natural and mechanical ones).

\section{The Hospital Wards and the Inpatient Room}

\subsection{General Requirements of the Inpatient Ward}

The inpatient ward is a low-medium care environment, with the presence of hospital staff and users with weak health conditions. Typically, a traditional inpatient ward has about $28-32$ beds with support services for medical activities and hospital staff, such as a nursing station, the head nurse office, several storages, a medical room, doctors' offices, a kitchenette, a workers' dining room and users' restrooms [18]. 
In this functional area, one of the most important pathogen sources is related to the respiration of a potentially infectious user and related medical activities; most of the inpatients spend a lot of their time in beds, while medical staff spend a lot of their time in a ward, depending on the activities to be carried out [32-35].

In general, they may be exposed to a wide range of chemical pollutants emitted from several products, such as finishing materials, furniture and disinfectants, and regular control plans, etc. [36].

The configuration of the inpatient room, as well as the design and health-related trends, is affected by: (a) environmental factors, dimensional space and design features; (b) managerial factors, related to medical procedures, training and health education, maintenance and cleaning activities, etc.; (c) social factors, guaranteeing hospitable spaces for users [37]. With regard to this latter aspect, several impacts of environmental features on health and wellbeing in hospitals can be subdivided into indoor air and thermo-hygrometric parameters, environmental safety, proper and efficient ventilation, acoustic noise, finishing materials, furniture, lighting, external views, wayfinding, colors, ergonomics, accessibility, etc. [38-41].

\subsection{Factors that Affect the Indoor Air Quality of Inpatient Rooms}

Since of the scientific literature reports give very different outputs and results, and the resulting work from the analysis conducted by Gola $[18,42]$ is divided into specific fields of interest, related to ventilation systems, construction and finishing materials, installations, components, etc.

Starting from an analysis already conducted by Gola et al. [18], it is possible to classify the factors of indoor air into four macro-areas [37]:

- Outdoor and indoor microclimatic factors, which refer to the outdoor air, the solar exposure and indoor microclimatic parameters, such as temperature, relative humidity, air velocity, air change, etc. Although these factors can vary, they have a great influence on the IAQ and the performances of materials in the room and air fluxes.

- Management activities, which refer to the management and maintenance activities, ventilation systems, cleaning and disinfectant activities, control plan, etc., carried out in the room and in the functional units and/or in the entire facility. They can highly affect IAQ, but their emissions can be controlled through the applications of strategies, and at the same time they can be changed if their actions are dangerous for users.

- Design factors, which refer to all the components that characterize the inpatient room (spaces' dimensions, furniture, finishing, etc.). In general, their emissions are constant, although in relation to their life, the emissions may decrease over the time.

- Human presence, which refers to the presence of users, their health status, and the medical activities carried out in the inpatient room. Their presence and application can vary, and therefore they can affect the indoor air in different modes.

As emerges from an analysis of the several factors, to overcome the criticisms related to the design of healing environments, interdisciplinary knowledge needs to be taken into account, including: the needs of users (hospital staff, patients, outpatients, visitors, etc.) related to their activities and therapies; nosocomial infections; applications of the technologies and ventilation systems (HVAC) needed to carry out the ordinary and specialist healthcare disciplines; risk analysis techniques for several functional units, including events caused by incorrect application of procedures; acceptable residual risk values and related sharing and management procedures [43].

In addition, designers, in collaboration with healthcare professionals, should design the healthcare settings according to the different uses, support the healthcare organization in identifying the most optimal solutions (for the daily technical, functional, economic and management aspects [44]), and elaborate and monitor the management and maintenance procedures of environments and systems. In addition, the managers should train the staff who will use or manage the spaces and systems, through the processing and updating of appropriate procedures, training courses and monitoring. 
Exposure of hospital users to chemical pollutions is related to several aspects, related to product formulations, how and where the products are applied, the methods of use, the degree of aging of the various components, the type of maintenance activity, etc. [30]. As some outputs of the analysis highlighted, the research field should more deeply explore exposure of hospital users through monitoring and assessments of exposure concentrations. In fact, as Bessonneau et al. observed, data have to be confirmed in a multi-centric approach, and research efforts must be designed with regard to the possible health effects induced after inhalation exposure to a complex mixture of chemical compounds [30].

\section{Strategies for Improving the IAQ in Inpatient Rooms}

\subsection{Definition of Check-Lists for Pre-Evaluating Performances of Inpatient Rooms}

Starting from the application of several case studies and the evidence given by a detailed analysis of the scientific literature [18], IAQ is a complex and challenging issue both for designers and hospital managers, and also for the National Health System (NHS). To pursue efficient levels of IAQ, and to reduce chemical pollutants in hospital environments, these compounds must be considered during design, construction and operational phases, as well as biological and physical ones [45-50]. As several scholars have demonstrated, many illnesses due to IAQ occur because indoor air has not been adequately considered in different phases, from the design to the management [51].

As the World Health Organization (WHO) and several Institutions have already highlighted, for understanding the real performances and the IAQ, it is proper to do several monitoring activities for an adequate data analysis, and for the investigating of the factors that affect this issue [51,52]. Although monitoring activities are preferred because they are more reliable, there are not always possible to set it up immediately, and data analysis requires a long time [53].

For this reason, for supporting designers and medical directors, the research team produces check-lists for the pre-assessment of chemical pollution in inpatient rooms, during the design phase, daily procedures and maintenance activities.

These check-lists aim to be useful tools for the pre-assessment and prior verification of strategies and decisions to be applied, and, when these cannot be verified, to have an awareness and take action for avoiding possible risks for the hospital users regarding chemical pollution. They become a preliminary tool to define a future and broad protocol for supporting the healthcare organizations in the strategies to be applied.

These lists refer to several criteria, considered as factors that affect IAQ (defined on the basis of the results of the analysis of present norms) the State of the Art, several research projects and investigations, and the systematic reviews by scientific international researchers, supported by reports promoted by the research group Study for the Indoor Air Pollution of Istituto Superiore di Sanità (National Institute for Health) in Italy [54]. The list of the references is reported in detail in each document. Each check-list is composed of several criteria, as follows: (a) field of interest-this section highlights the area of interest of the topic; (b) criterion-this section defines the argument and the topic of the criteria; (c) definition — this section defines the contents of the criteria; (d) requirement-this section lists the requisite to be met; (e) answer-this section is to be filled in for checking the requisites with "yes" or "no" answers ("not applicable" in the case of intervention not performed and delivered).

\subsubsection{Check-List for the Design Phase}

The aim of this check-list is to investigate and verify the design features of the room (dimensions, materials, etc.), its configuration and its installations. The check-list is particularly useful for designers and hospital planners during the design process.

The general scope of this list is to highlight possible deficiencies in the design phase, and to implement the project of the room through design strategies. This check-list is strongly related to the design of new healthcare facilities, or the renovation of an existing hospital. In this phase, the decision makers have a great responsibility, because it is possible to already define the management strategies, 
supported by the healthcare organization, for obtaining the best performances of the rooms, as well as of the cleaning and maintenance activities.

Starting from the answers, and in particular the negative ones, it will be possible to define strategies and solutions for improving the use and performances of the environmental unit for the medical activities.

In general, the check-list focuses on healthcare facilities with mechanical systems, responding to the current trends in hospital design.

As Table 1 shows, starting from the review of scientific reports, the check-list raises 18 topics, subdivided into 2 items related to room localization, 3 to microclimatic parameters, 4 to room configuration, 6 to ventilation system and 3 to materials and furniture.

Table 1. Check-list for the design phase.

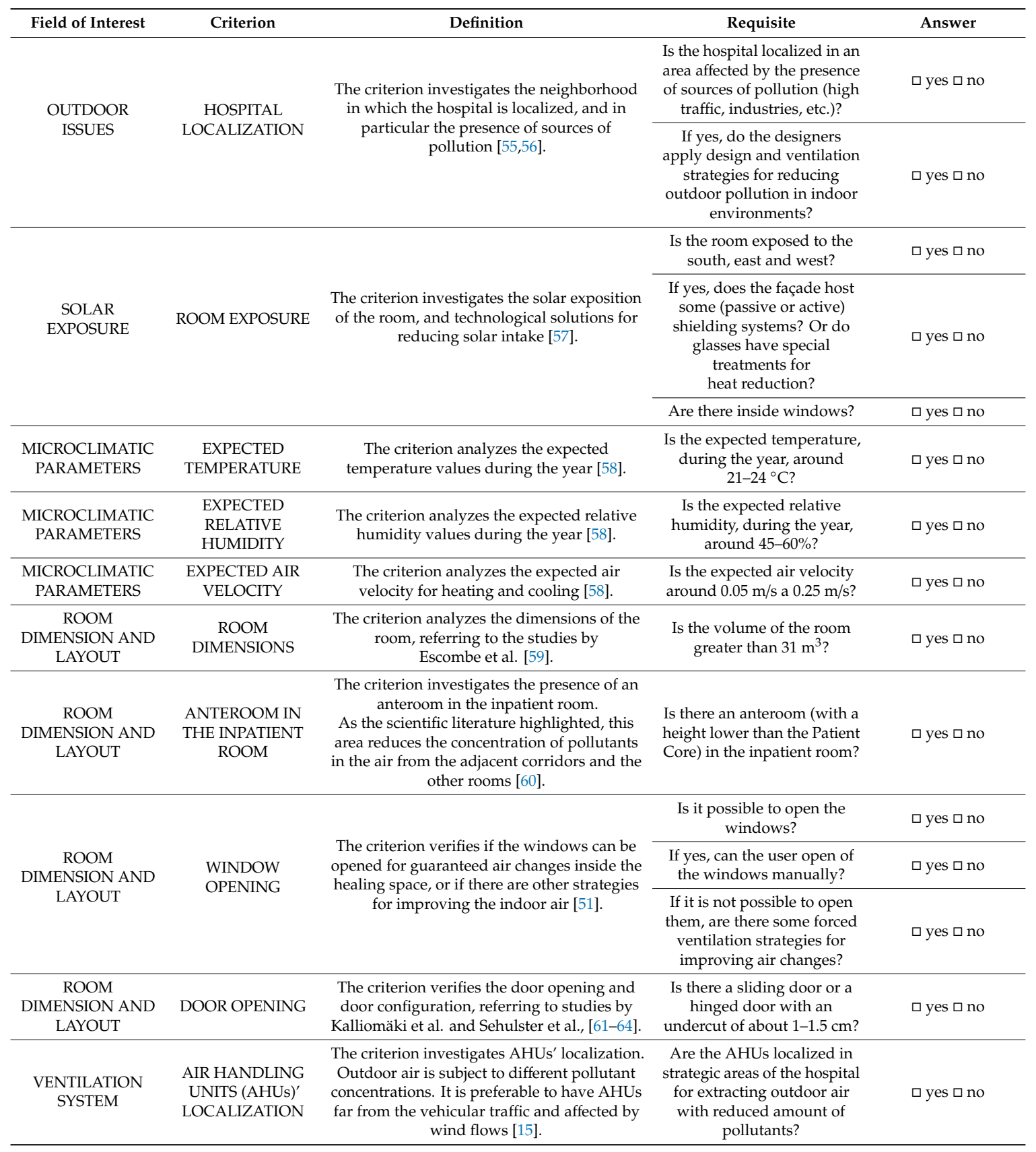


Table 1. Cont.

\begin{tabular}{|c|c|c|c|c|}
\hline Field of Interest & Criterion & Definition & Requisite & Answer \\
\hline $\begin{array}{l}\text { VENTILATION } \\
\text { SYSTEM }\end{array}$ & $\begin{array}{l}\text { FILTRATION } \\
\text { EFFIENCY }\end{array}$ & $\begin{array}{l}\text { The criterion verifies the air exchange rate } \\
\text { expected for inpatient room, as stated by the } \\
\text { American Society of Heating, Refrigerating } \\
\text { and Air-Conditioning Engineers (ASHRAE) } \\
170 \text { [58] and UNI EN ISO 16890:2017 [65]. }\end{array}$ & $\begin{array}{l}\text { Does the ventilation system } \\
\text { provide efficient filters (at } \\
\text { least, respectively, } 80 \%-85 \% \text {, } \\
99 \% \text { and } 75 \% \text { ) for air } \\
\text { pollution reduction? }\end{array}$ & $\square$ yes $\square$ no \\
\hline $\begin{array}{l}\text { VENTILATION } \\
\text { SYSTEM }\end{array}$ & EXCHANGE RATE & $\begin{array}{l}\text { The criterion verifies the air exchange rate } \\
\text { expected for inpatient room, as stated by } \\
\text { ASHRAE } 170 \text { [58] and Decree of the President } \\
\text { of the Italian Republic } 14 / 01 / 1997 \text { [66]. }\end{array}$ & $\begin{array}{l}\text { Does the inpatient room } \\
\text { have an air exchange rate } \\
\text { about } 4-6 \mathrm{vol} / \mathrm{h} \text { ? }\end{array}$ & $\square$ yes $\square$ no \\
\hline $\begin{array}{l}\text { VENTILATION } \\
\text { SYSTEM }\end{array}$ & $\begin{array}{l}\text { MECHANICAL } \\
\text { SYSTEM }\end{array}$ & $\begin{array}{l}\text { The criterion analyzes mechanical systems in } \\
\text { the hospital [67]. }\end{array}$ & $\begin{array}{l}\text { Does the air-handling } \\
\text { system provide variable air } \\
\text { volume? }\end{array}$ & $\square$ yes $\square$ no \\
\hline $\begin{array}{l}\text { VENTILATION } \\
\text { SYSTEM }\end{array}$ & $\begin{array}{l}\text { AIR FLOW } \\
\text { AMONG THE } \\
\text { ENVIRONMENTAL } \\
\text { UNITS }\end{array}$ & $\begin{array}{l}\text { The criterion verifies the presence of design } \\
\text { strategies for guaranteeing air flow among } \\
\text { the environmental units [67-69]. }\end{array}$ & $\begin{array}{l}\text { Is it ensured that the air flow } \\
\text { from one space to another } \\
\text { takes place through the slots } \\
\text { in the walls, ceilings, floors } \\
\text { and around the doors? }\end{array}$ & $\square$ yes $\square$ no \\
\hline $\begin{array}{l}\text { CONSTRUCTION } \\
\text { MATERIALS }\end{array}$ & $\begin{array}{l}\text { BUILDING } \\
\text { STRUCTURE }\end{array}$ & $\begin{array}{l}\text { The criterion considers the absorption level } \\
\text { of VOC levels of materials (e.g., painting, } \\
\text { adhesive and sealant, etc.). In fact, without } \\
\text { careful monitoring of the installation phases, } \\
\text { these materials can act as contaminant tanks, } \\
\text { releasing long-term re-emissions into the } \\
\text { indoor air [70]. }\end{array}$ & $\begin{array}{l}\text { Are the building structure } \\
\text { and construction materials } \\
\text { lower absorbent materials of } \\
\text { VOC levels? }\end{array}$ & $\square$ yes $\square$ no \\
\hline $\begin{array}{l}\text { FINISHING } \\
\text { MATERIALS and } \\
\text { FURNITURE }\end{array}$ & $\begin{array}{c}\text { MATERIALS' } \\
\text { PERFORMANCES }\end{array}$ & $\begin{array}{l}\text { The criterion verifies if the designers have } \\
\text { selected materials with minimal risks for } \\
\text { health and healthiness of spaces [71]. }\end{array}$ & $\begin{array}{l}\text { Have the designers selected } \\
\quad \text { certificated materials? } \\
\text { Or, do they analyze chemical } \\
\text { composition and emissivity } \\
\text { of the materials? }\end{array}$ & $\square$ yes $\square$ no \\
\hline
\end{tabular}

The check-list aims to highlight some criticisms, related mainly to negative answers, for identifying strategies and solutions to be applied, where possible, because each hospital project is different.

The following list (Table 2) suggests strategies to be taken into consideration for healthy performances of the inpatient ward.

\subsubsection{Check-List for Daily Procedures}

The check-list has the aim of investigating and verifying the daily procedures, the room occupancy and its performances. The aim of this list is to highlight possible deficiencies in medical and human activities, and to implement the procedures through management strategies.

Although design strategies require hard interventions, the check-list permits one to consider several factors and plan alternative actions related to the ventilation system (HVAC) and its efficiency, cleaning activities and detergents, a series of more specific activities of sanitation and disinfection, medical activities, and procedural adoption of prudential and adequate behavior.

Starting from the answers, and in particular the negative ones, it will be possible to define strategies and solutions for improving the use and performances of the environmental unit for the medical activities.

In general, the check-list focuses on healthcare facilities with mechanical systems.

As Table 3 shows, starting from the review of scientific reports, the check-list argues 20 topics, subdivided into 1 item related to room localization, 1 to room configuration, 3 to microclimatic parameters, 5 to ventilation system, 2 to medical activities, 6 to cleaning activities, 1 to human occupancy, and 1 to management activities. 
Table 2. Strategies for healthy outcomes of the project.

\begin{tabular}{|c|c|c|}
\hline Criterion & Criticism & Strategies \\
\hline outdoor issues-hospital localization & $\begin{array}{l}\text { If in the neighborhood there is the presence } \\
\text { of sources of pollution, }\end{array}$ & $\begin{array}{l}\text { high performances of ventilations systems } \\
\text { are required, with regular cleaning of the } \\
\text { filters, and it is requested to open the } \\
\text { windows only in case of need. }\end{array}$ \\
\hline solar exposure-room exposure, & $\begin{array}{l}\text { If the room has solar exposure (especially } \\
\text { south and west), and the façade and the } \\
\text { windows lack passive or active shielding } \\
\text { systems, or glasses lack special treatments } \\
\text { for heat reduction, }\end{array}$ & $\begin{array}{l}\text { it is suggested they introduce some internal } \\
\text { curtains, which comply with the hygiene } \\
\text { requirements for healing environments, to } \\
\text { reduce as much as possible the } \\
\text { accumulation of heat for avoiding the } \\
\text { emission of the VOC concentrations by the } \\
\text { materials and for maintaining adequate } \\
\text { microclimatic factors. }\end{array}$ \\
\hline $\begin{array}{c}\text { Microclimatic parameters-expected } \\
\text { temperature/relative humidity/ } \\
\text { air velocity. }\end{array}$ & $\begin{array}{l}\text { Although they are theoretical data to be } \\
\text { verified on site, if the project data do not } \\
\text { respect these requirements, }\end{array}$ & $\begin{array}{l}\text { it is requested they improve or reduce the } \\
\text { temperature/relative humidity and/or air } \\
\text { velocity through ventilation systems and/or } \\
\text { natural ventilation systems for adequate air } \\
\text { rate changes, and improving the } \\
\text { microclimatic parameters. }\end{array}$ \\
\hline $\begin{array}{l}\text { room dimension and layout- } \\
\text { room dimensions }\end{array}$ & If the volume is lower than $31 \mathrm{~m}^{3}$, & $\begin{array}{c}\text { it is requested they punctually improve the } \\
\text { air changes. }\end{array}$ \\
\hline $\begin{array}{l}\text { room dimension and layout-anteroom in } \\
\text { the inpatient room }\end{array}$ & $\begin{array}{l}\text { If there is not an anteroom in the } \\
\text { inpatient room, }\end{array}$ & $\begin{array}{l}\text { it is better to reduce the door opening, } \\
\text { introducing a window in the door for } \\
\text { supporting nurses' room control from } \\
\text { the corridor. }\end{array}$ \\
\hline $\begin{array}{l}\text { room dimension and layout- } \\
\text { window opening }\end{array}$ & $\begin{array}{l}\text { If it not is possible to open the } \\
\text { windows manually, }\end{array}$ & $\begin{array}{l}\text { it is suggested they acquire a smart system } \\
\text { that guarantees natural ventilation. }\end{array}$ \\
\hline $\begin{array}{l}\text { room dimension and layout- } \\
\text { door opening }\end{array}$ & $\begin{array}{l}\text { If there is not a sliding door or a hinged } \\
\text { door with an undercut of about } 1-1.5 \mathrm{~cm} \text {, }\end{array}$ & $\begin{array}{l}\text { it is requested they be careful during the } \\
\text { daily activities of door opening because of } \\
\text { the increased air movement between the } \\
\text { confined spaces. Major air intake systems } \\
\text { can control the air movement. }\end{array}$ \\
\hline ventilation system-AHU localization & $\begin{array}{l}\text { If the AHUs are not localized in strategic } \\
\text { areas of the hospital, }\end{array}$ & $\begin{array}{l}\text { it is suggested they verify during the design } \\
\text { phase possible other localizations, or define } \\
\text { maintenance and control activities for the } \\
\text { highest performances of the AHUs. }\end{array}$ \\
\hline ventilation system—filtration efficiency & $\begin{array}{l}\text { If the ventilation system does not provide } \\
\text { efficient filters for air pollution reduction, }\end{array}$ & $\begin{array}{l}\text { it is requested they improve the efficiency of } \\
\text { the filters in the mechanical systems. }\end{array}$ \\
\hline ventilation system-exchange rate & $\begin{array}{l}\text { Although they are theoretical data to be } \\
\text { verified on site, if the project data do not } \\
\text { respect the air exchange rate, }\end{array}$ & $\begin{array}{l}\text { it is requested they improve air exchange } \\
\text { rate and/or improve natural ventilation } \\
\text { strategies with window openings. }\end{array}$ \\
\hline ventilation system-mechanical system & $\begin{array}{l}\text { If the mechanical system does not provide } \\
\text { variable air volume, }\end{array}$ & $\begin{array}{l}\text { it is requested they introduce some } \\
\text { strategies for variable air volume and/or } \\
\text { improve natural ventilation strategies with } \\
\text { window openings. }\end{array}$ \\
\hline $\begin{array}{l}\text { ventilation system-air flow among the } \\
\text { environmental units }\end{array}$ & $\begin{array}{c}\text { If it is not ensured that the air flow from one } \\
\text { space to another takes place through the } \\
\text { slots in the walls, ceilings, floors and } \\
\text { around the doors, }\end{array}$ & $\begin{array}{c}\text { it is requested they introduce some design } \\
\text { strategies for guaranteeing air flow among } \\
\text { the spaces. }\end{array}$ \\
\hline ventilation system-expected pressure & $\begin{array}{l}\text { If the expected pressure is not positive in } \\
\text { the inpatient room, }\end{array}$ & $\begin{array}{l}\text { any action should be taken in this } \\
\text { consideration, starting from existing } \\
\text { legislation that does not list any specific } \\
\text { requirements. In any case, it is suggested } \\
\text { they place air intake systems near the door } \\
\text { and windows openings. }\end{array}$ \\
\hline $\begin{array}{l}\text { construction materials- } \\
\text { building structure }\end{array}$ & $\begin{array}{l}\text { If there are materials of high/medium VOC } \\
\text { absorbent levels, }\end{array}$ & $\begin{array}{l}\text { it is suggested they select materials with } \\
\text { low VOC concentrations. Where this is not } \\
\text { possible, it is necessary they guarantee } \\
\text { adequate air rate change, especially in the } \\
\text { first months after laying, and avoid high } \\
\text { solar exposure. }\end{array}$ \\
\hline $\begin{array}{l}\text { finishing materials and } \\
\text { furniture-materials' performances }\end{array}$ & $\begin{array}{l}\text { If the designers have not selected } \\
\text { certificated materials (or if the healthcare } \\
\text { organization has not imposed any } \\
\text { certificated materials), }\end{array}$ & $\begin{array}{l}\text { it is suggested they select certificated } \\
\text { materials. Where this is not possible, it is } \\
\text { necessary to guarantee adequate air rate } \\
\text { change, especially in the first months after } \\
\text { laying, and to avoid high solar exposure. }\end{array}$ \\
\hline $\begin{array}{l}\text { finishing materials and } \\
\text { furniture-materials' performances }\end{array}$ & $\begin{array}{l}\text { If the designers have not selected durable } \\
\text { materials and surfaces that facilitate } \\
\text { cleaning and maintenance activities (or if } \\
\text { the healthcare organization has imposed } \\
\text { specific materials), }\end{array}$ & $\begin{array}{l}\text { it is suggested they introduce adequate } \\
\text { finishing materials, able to be cleaned with } \\
\text { cleaning products with low VOC } \\
\text { concentrations. }\end{array}$ \\
\hline
\end{tabular}


Table 3. Check-list for daily procedures.

\begin{tabular}{|c|c|c|c|c|}
\hline Field of Interest & Criterion & Definition & Requisite & Answer \\
\hline \multirow[b]{2}{*}{$\begin{array}{l}\text { SITE CONSTRUCTIONS IN } \\
\text { THE NEIGHBORHOOD }\end{array}$} & \multirow[b]{2}{*}{ SITE CONSTRUCTION } & \multirow{2}{*}{$\begin{array}{l}\text { The criterion verifies the presence of a site construction in the } \\
\text { surroundings or inside the hospital, and possible influence on the } \\
\text { hospital building }[55,56] .\end{array}$} & $\begin{array}{l}\text { Are there some site constructions inside of } \\
\text { the hospital, the hospital borders or in the } \\
\text { neighborhood of the hospital? }\end{array}$ & $\square$ yes $\square$ no \\
\hline & & & $\begin{array}{l}\text { If yes, are there some procedures in place to } \\
\text { prevent renovation and remodeling activities } \\
\text { from adversely affecting the building } \\
\text { air supply? }\end{array}$ & $\square$ yes $\square$ no \\
\hline \multirow[b]{2}{*}{$\begin{array}{l}\text { ROOM DIMENSION AND } \\
\text { LAYOUT }\end{array}$} & \multirow[b]{2}{*}{ WINDOW OPENING } & \multirow[b]{2}{*}{$\begin{array}{l}\text { The criterion verifies if the windows can be opened for guaranteeing air } \\
\text { changes inside the healing space [51]. }\end{array}$} & Is it possible to open the windows? & $\square$ yes $\square$ no \\
\hline & & & $\begin{array}{l}\text { If it is not possible, are there some forced } \\
\text { ventilation strategies for improving } \\
\text { air changes? }\end{array}$ & $\square$ yes $\square$ no \\
\hline $\begin{array}{l}\text { MICROCLIMATIC } \\
\text { PARAMETERS }\end{array}$ & TEMPERATURE & The criterion analyzes the temperature values during the year $[58,72]$. & $\begin{array}{l}\text { Is the temperature, during the year, around } \\
\qquad 21-24^{\circ} \mathrm{C} \text { ? }\end{array}$ & $\square$ yes $\square$ no \\
\hline $\begin{array}{l}\text { MICROCLIMATIC } \\
\text { PARAMETERS }\end{array}$ & RELATIVE HUMIDITY & $\begin{array}{l}\text { The criterion analyzes the relative humidity values during the } \\
\text { year }[58,72] .\end{array}$ & $\begin{array}{l}\text { Is the relative humidity, during the year, } \\
\text { around } 40-60 \% \text { ? }\end{array}$ & $\square$ yes $\square$ no \\
\hline \multirow{2}{*}{$\begin{array}{l}\text { MICROCLIMATIC } \\
\text { PARAMETERS }\end{array}$} & \multirow[b]{2}{*}{ AIR VELOCITY } & \multirow[b]{2}{*}{ The criterion analyzes the air velocity for heating and cooling $[58,72]$. } & $\begin{array}{l}\text { Is the air velocity, for heating, around } 0.05 \\
\mathrm{~m} / \mathrm{s} \text { to } 0.20 \mathrm{~m} / \mathrm{s} \text { ? }\end{array}$ & $\square$ yes $\square$ no \\
\hline & & & $\begin{array}{l}\text { Is the air velocity, for cooling, around } 0.05 \\
\mathrm{~m} / \mathrm{s} \text { to } 0.25 \mathrm{~m} / \mathrm{s} \text { ? }\end{array}$ & $\square$ yes $\square$ no \\
\hline VENTILATION SYSTEM & CROWD INDEX & The criterion analyzes the crowd index $[58,72,73]$. & $\begin{array}{l}\text { Is the crowd index predicted for the } \\
\text { environmental unit } 0.08 \text { ? }\end{array}$ & $\square$ yes $\square$ no \\
\hline VENTILATION SYSTEM & AIR FLOW vs CROWD INDEX & $\begin{array}{l}\text { The criterion analyzes the relationship between air flow and crowd } \\
\text { index [58]. }\end{array}$ & $\begin{array}{l}\text { Depending on the crowding, is the air flow } \geq \\
11 \text { liters/s per person? }\end{array}$ & $\square$ yes $\square$ no \\
\hline VENTILATION SYSTEM & EXCHANGE RATE & The criterion verifies the air exchange rate for the inpatient room [58]. & $\begin{array}{l}\text { Does the inpatient room have an air } \\
\text { exchange rate about } 4-6 \mathrm{vol} / \mathrm{h} \text { ? }\end{array}$ & $\square$ yes $\square$ no \\
\hline VENTILATION SYSTEM & AIR FLOW & The criterion investigates the air flow rate in the inpatient room [73]. & $\begin{array}{l}\text { Is the air flow rate between inlet and } \\
\text { discharge maintained? }\end{array}$ & $\square$ yes $\square$ no \\
\hline VENTILATION SYSTEM & PRESSURE & $\begin{array}{l}\text { The criterion analyzes the pressure in the inpatient room, although } \\
\text { legislation does not list any specific requirement. }\end{array}$ & $\begin{array}{l}\text { Is the expected pressure of the inpatient } \\
\text { room positive? }\end{array}$ & $\square$ yes $\square$ no \\
\hline \multirow{2}{*}{ MEDICAL ACTIVITY } & \multirow{2}{*}{$\begin{array}{l}\text { MEDICAL ACTIVITIES AND } \\
\text { THERAPIES }\end{array}$} & \multirow{2}{*}{$\begin{array}{l}\text { The criterion verifies the presence of medical activities in the inpatient } \\
\text { room that can affect the quality of the air, as Lu at al. and Hsu et al. } \\
\text { observed [74,75]. }\end{array}$} & $\begin{array}{l}\text { Are there some medical treatments carried } \\
\text { out in the inpatient room that could affect the } \\
\text { quality of the air? }\end{array}$ & $\square$ yes $\square$ no \\
\hline & & & $\begin{array}{l}\text { If yes, are there some procedures for diluting } \\
\text { pollution levels? }\end{array}$ & $\square$ yes $\square$ no \\
\hline
\end{tabular}


Table 3. Cont.

\begin{tabular}{|c|c|c|c|c|}
\hline Field of Interest & Criterion & Definition & Requisite & Answer \\
\hline \multirow[t]{2}{*}{ MEDICAL ACTIVITY } & \multirow[t]{2}{*}{ MEDICAL EQUIPMENT } & \multirow{2}{*}{$\begin{array}{l}\text { Plastic infusion bags, blood bags, plastic film, injectors, etc., can emit low } \\
\text { concentrations of pollutants [76]. The criterion investigates if this } \\
\text { equipment is used, and if they can affect the breathing zone. }\end{array}$} & $\begin{array}{l}\text { Are there some medical equipment that can } \\
\text { emit chemical pollutants in the breathing } \\
\text { zone? }\end{array}$ & $\square$ yes $\square$ no \\
\hline & & & $\begin{array}{l}\text { If yes, are they rather distant from breathing } \\
\text { zone? }\end{array}$ & $\square$ yes $\square$ no \\
\hline CLEANING ACTIVITY & $\begin{array}{l}\text { NUMBER of CLEANING } \\
\text { ACTIVITIES per DAY }\end{array}$ & $\begin{array}{l}\text { The criterion verifies the frequency of cleaning activities for inpatient } \\
\text { rooms [51]. }\end{array}$ & $\begin{array}{l}\text { Is the room cleaned, properly, at least twice a } \\
\text { day? }\end{array}$ & $\square$ yes $\square$ no \\
\hline CLEANING ACTIVITY & CLEANED AREAS & The criterion verifies the areas cleaned daily [72]. & $\begin{array}{l}\text { Is there floor, furniture and bathroom } \\
\text { cleaning every day? }\end{array}$ & $\square$ yes $\square$ no \\
\hline \multirow[t]{2}{*}{ CLEANING ACTIVITY } & \multirow[t]{2}{*}{$\begin{array}{l}\text { FLOOR CLEANING } \\
\text { PRODUCTS }\end{array}$} & \multirow[t]{2}{*}{$\begin{array}{l}\text { The criterion verifies the contents of detergents for floor cleaning, and if } \\
\text { they affect the performance of the floor [56]. }\end{array}$} & $\begin{array}{l}\text { Are the floors cleaned with detergents with } \\
\text { chlorine-derivatives, quaternary ammonium } \\
\text { salts or phenol? }\end{array}$ & $\square$ yes $\square$ no \\
\hline & & & $\begin{array}{l}\text { Are the detergents affecting the performance } \\
\text { of floors? }\end{array}$ & $\square$ yes $\square$ no \\
\hline \multirow[t]{2}{*}{ CLEANING ACTIVITY } & \multirow[t]{2}{*}{$\begin{array}{l}\text { FURNITURE CLEANING } \\
\text { PRODUCTS }\end{array}$} & \multirow[t]{2}{*}{$\begin{array}{l}\text { The criterion verifies the contents of detergents for furniture cleaning, } \\
\text { and if they affect the performance of furniture [77]. }\end{array}$} & $\begin{array}{l}\text { Is the furniture cleaned with detergents with } \\
\text { quaternary ammonium salts, phenol or } \\
\text { alcohols? }\end{array}$ & $\square$ yes $\square$ no \\
\hline & & & $\begin{array}{l}\text { Are detergents affecting the performance of } \\
\text { furniture? }\end{array}$ & $\square$ yes $\square$ no \\
\hline CLEANING ACTIVITY & $\begin{array}{l}\text { BATHROOM CLEANING } \\
\text { PRODUCTS }\end{array}$ & $\begin{array}{l}\text { The criterion verifies the contents of detergents for bathroom cleaning } \\
\text { [77]. }\end{array}$ & $\begin{array}{l}\text { Is the bathroom cleaned with detergents with } \\
\text { chlorine-derivatives, quaternary ammonium } \\
\text { salts or phenol? }\end{array}$ & $\square$ yes $\square$ no \\
\hline \multirow[t]{2}{*}{ CLEANING ACTIVITY } & \multirow{2}{*}{$\begin{array}{l}\text { AIR CHANGE DURING and } \\
\text { AFTER CLEANING ACTIVITY }\end{array}$} & \multirow{2}{*}{$\begin{array}{l}\text { The criterion verifies if windows are opened during and after cleaning } \\
\text { activities [78]. }\end{array}$} & $\begin{array}{l}\text { Are windows opened during and after } \\
\text { cleaning activities for } 15-20 \text { minutes? }\end{array}$ & $\square$ yes $\square$ no \\
\hline & & & $\begin{array}{l}\text { If it is not possible, are there some forced } \\
\text { ventilation strategies for improving air } \\
\text { changes? }\end{array}$ & $\square$ yes $\square$ no \\
\hline HUMAN PRESENCE & SMOCKING ACTIVITY & $\begin{array}{l}\text { The criterion investigates the presence of warnings and design strategies } \\
\text { applied for avoiding smoking in the healing environments. It is } \\
\text { well-known that smoking can highly affect the indoor values [18,79]. }\end{array}$ & $\begin{array}{l}\text { Are there any smoking restrictions in the } \\
\text { inpatient room or in the inpatient ward, or } \\
\text { outside? }\end{array}$ & $\square$ yes $\square$ no \\
\hline MAINTENANCE ACTIVITY & SAMPLING ACTIVITY & $\begin{array}{l}\text { The criterion verifies if there are some monitoring activities for IAQ in } \\
\text { the inpatient ward [72]. }\end{array}$ & $\begin{array}{l}\text { Are there some sampling activities for } \\
\text { registering the indoor air in the inpatient } \\
\text { ward? }\end{array}$ & $\square$ yes $\square$ no \\
\hline
\end{tabular}


The check-list aims to highlight some criticisms, related mainly to negative answers, for identifying strategies and solutions to be applied, where possible, because each healthcare project is different.

The following list (Table 4) suggests strategies to be taken into consideration for healthy performances of the inpatient ward during the daily procedures.

Table 4. Strategies for healthy outcomes in daily procedures.

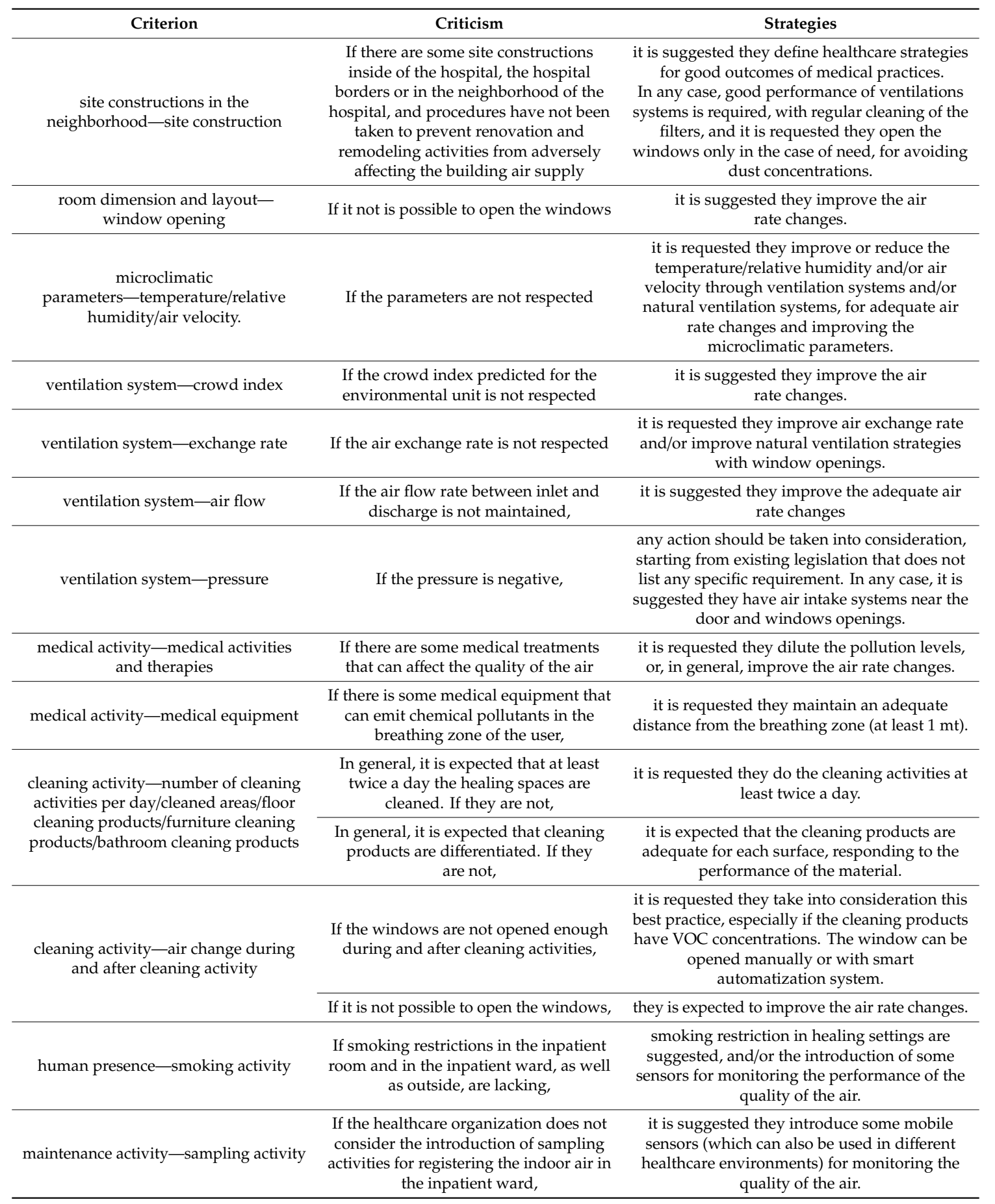




\subsubsection{Check-List for Maintenance Activities and Interventions}

The check-list has the aim of investigating and verifying the condition of the room after the maintenance activity and/or intervention.

The aim of this list is to highlight possible deficiencies of the room and procedures before occupation of the room by users, and to apply management strategies.

The type of interventions can be different (extra-ordinary maintenance with furniture installation, pipe cleaning, etc.), i.e., hard or soft interventions in the room. In relation to complexity, the strategies may concern natural ventilation or HVAC systems and efficiency, medical activities and management procedures, the planning of cleaning and disinfection, activities' assessment, and actions related to air monitoring for both chemical and biological agents.

Starting from the answers, and in particular the negative ones, it will be possible to define strategies and solutions for improving the use and performances of the environmental unit for medical activities.

In general, the check-list focuses on healthcare facilities with mechanical systems.

As Table 5 shows, starting from the review of the scientific reports, the check-list argues 13 topics, subdivided into 1 item related to room configuration, 5 to materials and furniture, 3 to maintenance activities, and 4 to cleaning activities.

The check-list aims to highlight some criticisms, related mainly to negative answers, for identifying strategies and solutions to be applied, where possible, because each activity requires different attentions.

The following list (Table 6) suggests strategies to be taken into consideration for healthy performances during maintenance activities and interventions. 
Table 5. Check-list for maintenance activities and interventions.

\begin{tabular}{|c|c|c|c|c|}
\hline Field of Interest & Criterion & Definition & Requisite & Answer \\
\hline \multirow{3}{*}{$\begin{array}{l}\text { ROOM DIMENSION AND } \\
\text { LAYOUT }\end{array}$} & \multirow{3}{*}{ TYPE OF INTERVENTION } & \multirow{3}{*}{$\begin{array}{l}\text { The criterion investigates the typology of intervention applied in the room. In relation } \\
\text { to the activities carried out, it is possible to develop several considerations related to } \\
\text { management strategies to be applied [55,56]. }\end{array}$} & $\begin{array}{l}\text { Do the interventions involve hard modifications of } \\
\text { the room? }\end{array}$ & $\square$ yes $\square$ no \\
\hline & & & $\begin{array}{l}\text { If not, do the interventions involve punctual } \\
\text { modifications of the room? }\end{array}$ & $\square$ yes $\square$ no \\
\hline & & & $\begin{array}{l}\text { If not, do the interventions involve maintenance } \\
\text { activities on the installations and/or ventilation } \\
\text { pipes of the room and/or inpatient ward? }\end{array}$ & $\square$ yes $\square$ no \\
\hline \multirow[b]{2}{*}{ CONSTRUCTION MATERIALS } & \multirow[b]{2}{*}{$\begin{array}{l}\text { MATERIALS' } \\
\text { CERTIFICATIONS }\end{array}$} & \multirow[b]{2}{*}{$\begin{array}{l}\text { The criterion verifies if the designers have selected materials with minimal risks for } \\
\text { health and healthy spaces [71]. }\end{array}$} & Have the designers selected certificated materials? & $\square$ yes $\square$ no $\square$ not applicable \\
\hline & & & $\begin{array}{l}\text { If not, do they analyze chemical composition and } \\
\text { emissivity of materials, selecting the } \\
\text { healthier ones? }\end{array}$ & $\square$ yes $\square$ no $\square$ not applicable \\
\hline CONSTRUCTION MATERIALS & $\begin{array}{c}\text { MATERIALS' } \\
\text { PERFORMANCES }\end{array}$ & $\begin{array}{c}\text { The criterion verifies if the designers have selected durable materials that facilitate } \\
\text { cleaning activity [80]. }\end{array}$ & $\begin{array}{l}\text { Do the designers select durable materials that } \\
\text { facilitate cleaning and maintenance activities? }\end{array}$ & $\square$ yes $\square$ no $\square$ not applicable \\
\hline FINISHING MATERIALS & MATERIALS LAYING & $\begin{array}{l}\text { The criterion investigates the completeness of the work performed and the } \\
\text { performances of materials [80]. }\end{array}$ & Have the materials been laid correctly? & $\square$ yes $\square$ no $\square$ not applicable \\
\hline FINISHING MATERIALS & MATERIALS TREATMENT & $\begin{array}{l}\text { The criterion investigates the treatments adopted for improving materials' } \\
\text { performances (linoleum, wood, etc.) [80]. }\end{array}$ & $\begin{array}{l}\text { Have finishing materials been treated with } \\
\text { chemical agents to improve their performance? }\end{array}$ & $\square$ yes $\square$ no $\square$ not applicable \\
\hline FURNITURE & FURNITURE INSTALLATION & $\begin{array}{l}\text { The criterion investigates the completeness of furniture installation, without any } \\
\text { damages to the material that can affect the performance of the materials }[18,72] \text {. }\end{array}$ & Has the furniture been installed correctly? & $\square$ yes $\square$ no $\square$ not applicable \\
\hline MAINTENANCE ACTIVITY & VENTILATION SYSTEM & $\begin{array}{l}\text { Although typical ventilation systems are not affected by chemical pollution, the risk can } \\
\text { be caused by the introduction of inadequate cleaning products. The criterion evaluates } \\
\text { the products used for cleaning ventilation pipes. } \\
\text { For this reason, the number of cleaning activities is not compulsory, even if inadequate } \\
\text { cleaning products do not affect the indoor air [15]. }\end{array}$ & $\begin{array}{l}\text { Has the ventilation system been cleaned properly, } \\
\text { with the use of adequate cleaning agents } \\
\text { and disinfectants? }\end{array}$ & $\square$ yes $\square$ no $\square$ not applicable \\
\hline MAINTENANCE ACTIVITY & $\begin{array}{l}\text { ACTIONS AFTER } \\
\text { INSTALLATION }\end{array}$ & $\begin{array}{l}\text { The criterion verifies if the managers of the hospital have guaranteed adequate } \\
\text { ventilation in the room for emissions' reduction after the installation/intervention [81]. }\end{array}$ & $\begin{array}{l}\text { Have the managers guaranteed the adequate } \\
\text { ventilation for a minimum of } 72 \mathrm{~h} \text { after products' } \\
\text { installation/intervention? }\end{array}$ & $\square$ yes $\square$ no \\
\hline \multirow[b]{2}{*}{ MAINTENANCE ACTIVITY } & \multirow[b]{2}{*}{ ROOM OCCUPANCY } & \multirow{2}{*}{$\begin{array}{l}\text { The criterion investigates the regular occupation of the room [81]. } \\
\text { The intervention/installation in the first months can cause high emissions of pollution } \\
\text { (whose peaks are registered in the first days after installation), so it is essential to ensure } \\
\text { a ventilation rate greater than normal conditions in order to eliminate contaminants } \\
\text { from the indoor settings [81]. }\end{array}$} & $\begin{array}{c}\text { Is the inpatient room regularly occupied by users, } \\
\text { after a few days from the interventions? }\end{array}$ & $\square$ yes $\square$ no \\
\hline & & & $\begin{array}{l}\text { Is there a ventilation rate greater than normal } \\
\text { conditions, in order to dilute contaminants from } \\
\text { the room? }\end{array}$ & $\square$ yes $\square$ no \\
\hline CLEANING ACTIVITY & $\begin{array}{l}\text { ROOM CLEANING AFTER } \\
\text { INTERVENTION }\end{array}$ & $\begin{array}{l}\text { After maintenance activities and interventions, the hygienic conditions of the room are } \\
\text { not adequate for users' health status. For this reason, the criterion verifies if the room } \\
\text { has been cleaned properly }[77,81] \text {. }\end{array}$ & $\begin{array}{l}\text { Has the room been cleaned properly after } \\
\text { the intervention? }\end{array}$ & $\square$ yes $\square$ no $\square$ not applicable \\
\hline CLEANING ACTIVITY & $\begin{array}{l}\text { ROOM CLEANING AFTER } \\
\text { INTERVENTION }\end{array}$ & $\begin{array}{l}\text { The criterion investigates the composition of detergents, verifying the consistency of the } \\
\text { cleaning products on finishing and furniture [51]. }\end{array}$ & $\begin{array}{l}\text { Do the cleaning products comply with } \\
\text { finishing materials? }\end{array}$ & $\square$ yes $\square$ no $\square$ not applicable \\
\hline \multirow{2}{*}{ CLEANING ACTIVITY } & \multirow{2}{*}{$\begin{array}{l}\text { AIR CHANGE AFTER } \\
\text { (EXTRA-ORDINARY) } \\
\text { CLEANING ACTIVITY }\end{array}$} & \multirow{2}{*}{$\begin{array}{l}\text { The criterion verifies if an adequate air change has been guaranteed in the room after } \\
\text { the (extra-ordinary) cleaning activity }[80,82] \text {. }\end{array}$} & $\begin{array}{l}\text { Have the cleaners opened the windows after } \\
\text { (extra-ordinary) cleaning activities? }\end{array}$ & $\square$ yes $\square$ no $\square$ not applicable \\
\hline & & & $\begin{array}{l}\text { If it is not possible to open the windows, have } \\
\text { some forced ventilation strategies been applied for } \\
\text { improving air changes? }\end{array}$ & $\square$ yes $\square$ no $\square$ not applicable \\
\hline CLEANING ACTIVITY & WINDOWS WASHING & $\begin{array}{l}\text { The criterion verifies the detergents used for (extra-ordinary) windows washing in the } \\
\text { inpatient rooms [51]. }\end{array}$ & $\begin{array}{l}\text { Are the windows washed with detergents with } \\
\text { alcohols or phenol? }\end{array}$ & $\square$ yes $\square$ no $\square$ not applicable \\
\hline
\end{tabular}


Table 6. Strategies for healthy outcomes for maintenance activities and interventions.

\begin{tabular}{|c|c|c|}
\hline Criterion & Criticism & Strategies \\
\hline room dimension and layout—-type of intervention & In relation to the hard or soft maintenance activities to be done, & $\begin{array}{l}\text { it is requested they pay attention to the healthcare flows and define all the } \\
\text { useful actions for reducing the potential risks for the users. }\end{array}$ \\
\hline construction materials-materials' certifications & $\begin{array}{l}\text { If the designers have not selected certificated materials (or the } \\
\text { healthcare organization has not imposed any certificated } \\
\text { materials), }\end{array}$ & $\begin{array}{l}\text { it is suggested they select certificated materials. Where it is not possible, it is } \\
\text { necessary to guarantee adequate air rate change, especially in the first months } \\
\text { after laying, and to avoid high solar exposure. }\end{array}$ \\
\hline $\begin{array}{c}\text { construction materials—-materials' performances/materials } \\
\text { laying/materials treatment }\end{array}$ & $\begin{array}{l}\text { If the designers have not selected durable materials and surfaces } \\
\text { that facilitate cleaning and maintenance activities (or the } \\
\text { healthcare organization has not imposed specific materials), }\end{array}$ & $\begin{array}{l}\text { it is suggested they introduce adequate finishing materials, able to be cleaned } \\
\text { with cleaning products with low VOC concentrations. Where it is not possible, } \\
\text { it is necessary to guarantee adequate air rate change, especially in the first } \\
\text { months after laying, and to avoid high solar exposure. }\end{array}$ \\
\hline furniture-furniture installation & If the furniture has not been installed correctly, & $\begin{array}{l}\text { it is requested they guarantee adequate air rate change, especially in the first } \\
\text { months after furniture installation, and avoid high solar exposure. }\end{array}$ \\
\hline ventilation system-exchange rate & If it is not respect the air exchange rate, & $\begin{array}{l}\text { it is requested they improve air exchange rate and/or improve natural } \\
\text { ventilation strategies with window openings. }\end{array}$ \\
\hline ventilation system-air flow & If the air flow rate between inlet and discharge is not maintained, & it is suggested they improve the adequate air rate changes. \\
\hline ventilation system - pressure & If the pressure is negative, & $\begin{array}{l}\text { any action should be taken into consideration, starting from existing } \\
\text { legislation that does not list any specific requirement. In any case, it is } \\
\text { suggested they have air intake systems near the door and window openings. }\end{array}$ \\
\hline maintenance activity—ventilation system/actions after installation & If the ventilation system has not been cleaned properly, & $\begin{array}{l}\text { it is suggested they use proper detergents, and guarantee adequate ventilation } \\
\text { for a minimum of } 72 \mathrm{~h} \text { after products' installation/intervention. }\end{array}$ \\
\hline maintenance activity—room occupancy & $\begin{array}{l}\text { If the room needs to regularly occupied by users a few days after } \\
\text { the interventions, }\end{array}$ & $\begin{array}{l}\text { it is requested they guarantee adequate air rate change, especially in the first } \\
\text { days after the intervention. }\end{array}$ \\
\hline \multirow{2}{*}{$\begin{array}{l}\text { cleaning activity - room cleaning after intervention/air change after } \\
\text { (extra-ordinary) cleaning activity }\end{array}$} & $\begin{array}{l}\text { In general, it is expected that adequate cleaning activities have } \\
\text { been done correctly and cleaning products have been adequate } \\
\text { for each surface. If it is not, }\end{array}$ & $\begin{array}{l}\text { it is expected that the cleaning products are adequate for each surface, } \\
\text { responding to the performance of the material. }\end{array}$ \\
\hline & $\begin{array}{l}\text { If an adequate air change has not been guaranteed in the room } \\
\text { after the (extra-ordinary) cleaning activity, }\end{array}$ & $\begin{array}{l}\text { it is requested they improve the natural or mechanical air rate changes before } \\
\text { the use of the users. }\end{array}$ \\
\hline cleaning activity—windows washing & If the windows are not washed with adequate detergents, & $\begin{array}{l}\text { it is requested they use adequate products for the surface, responding to the } \\
\text { performance of the material. In any case, adequate air change can reduce the } \\
\text { VOC emissions. }\end{array}$ \\
\hline
\end{tabular}




\section{Conclusions and Future Perspectives}

It is clear that IAQ is a very broad topic, in which any variable can affect the performance of air in indoor environments. In fact, design and management strategies which may be adequate in relation to different procedures can decrease or increase the quality performances of the inpatient room, and the comfort of users [83,84].

Although current monitoring activities and data analyses are more reliable, the check-lists become useful tools for a pre-assessment and prior verification of strategies and decisions to be applied, and when they cannot be verified, they help one to have awareness and take action for avoiding possible risks to the users.

The multidisciplinary approach, supported by design, chemical and healthcare issues, demonstrates the need for interdisciplinary of knowledges and skills aimed at finding solutions able to protect the health status of users [85]. It is clear that the design and management decision-making, including the adequate choice of the construction site and hospital exposure [55,56], finishing materials and furniture [86-88], cleaning and maintenance activities [77,89], etc., which can affect the IAQ, must be carried out on the basis of scientific research and data. It is necessary that the decision-making team should be composed of several professionals, for guaranteeing a multidisciplinary and synergic design project.

The hospital system should be rethought, giving attention to the pollutant emissions, and providing buildings that, from the design phase up to the building's realization and functioning, can maintain the safe conditions of the indoor environment $[68,69,90]$. In this regard, it is worth underlining that, for emission control, it is not enough only to define engineering plans and design solutions, but it is essential to consider all the factors and medical and maintenance procedures [89].

The paper aims at the elaboration of strategies for health promotion in hospital wards, from the chemical pollution point of view. In any case, it is possible to consider improvements, all the time, to the contents of the check-lists, thanks to the support of several research groups, the data analysis and monitoring activities supported by scientific methodologies, such as those of Gola et al. and Śmiełowska et al. [10,76], which are useful tools for supporting designers and managers, as well as all the users who can actively contribute to the reduction of health risks (which highlights the importance of users' behavior and hygienic aspects) [31,91].

These activities help the healthcare organization and hospital staff, with a view to preventions and the planning of interventions into the activities and the use of sanitizing or disinfectant substances related to medical activities, and also helping them to be ready in the case of epidemics (i.e., SARS-CoV-2), particularly regarding the activity of disinfection [92].

Among the future perspectives, the new challenge is to investigate the correlations between the chemical and biological pollutants, and their effects on IAQ and the quality of the healthcare facility.

Author Contributions: Conceptualization, M.G.; Methodology, M.G., G.S., and S.C.; Investigation, M.G. and G.S.; Data curation, M.G. and S.C.; Writing—original draft preparation, M.G.; Writing—review and editing, M.G. and G.S.; Supervision, S.C.; Project administration, G.S. All authors have read and agreed to the published version of the manuscript.

Funding: This research received no external funding.

Conflicts of Interest: The authors declare no conflicts of interest.

\section{Abbreviations}

$\begin{array}{ll}\text { AHUs } & \text { Air Handling Units } \\ \text { ASHRAE } & \text { American Society of Heating, Refrigerating and Air-Conditioning Engineers } \\ \text { HAIs } & \text { Hospital Acquired Infections } \\ \text { HVAC } & \text { Heating, Ventilation, and Air Conditioning systems } \\ \text { IAQ } & \text { Indoor Air Quality } \\ \text { IEQ } & \text { Indoor Environmental Quality } \\ \text { NHS } & \text { National Health System }\end{array}$


SARS-CoV-2 Severe acute respiratory syndrome Coronavirus 2

VOCs Volatile Organic Compounds

WHO World Health Organization

\section{References}

1. Settimo, G.; D'Alessandro, D. European community guidelines and standards in indoor air quality: What proposals for Italy. Epidemiol. Prev. 2014, 38, 36-41. [PubMed]

2. Fanger, P.O.; Melikov, A.K.; Hanzawa, H.; Ring, J. Air turbulence and sensation of draught. Energy Build. 1988, 12, 21-39. [CrossRef]

3. Settimo, G.; Bertinato, L.; Bonadonna, L.; D'Ancona, P.; Santarsiero, A.; Soggiu, M.E. Indicazioni ad Interim per la Prevenzione e Gestione Degli Ambienti Indoor in Relazione Alla Trasmissione Dell'infezione da Virus SARS-CoV-2. Rapp. ISS COVID-19. 2020, p. 5. Available online: https:/www.iss.it/documents/20126/0/Rapporto+ ISS+COVID-19+n.+5_2020+REV.pdf/2d27068f-6306-94ea-47e8-0539f0119b91?t=1588146889381 (accessed on 15 June 2020).

4. d'Ambrosio Alfano, F.R.; Olesen, B.W.; Palella, B.I. Povl Ole Fanger's Impact Ten Years Later. Energy Build. 2017, 152, 243-249. [CrossRef]

5. World Health Organization. Indoor Air Pollutants: Exposure and Health Effects; World Health Organization, EURO Reports and Studies 1978; World Health Organization: Copenhagen, Denmark, 1983.

6. Viviano, G.; Settimo, G. Air quality regulation and implementation of the European Council Directives. Annali dell'Istituto Super. Sanit. 2003, 39, 343-350.

7. D'Alessandro, D.; Fara, G.M. Hospital Environments and Epidemiology of Healthcare-Associated Infections. In Indoor Air Quality in Healthcare Facilities, 1st ed.; Capolongo, S., Settimo, G., Gola, M., Eds.; Springer Public Health: New York, NY, USA, 2017; pp. 41-52. [CrossRef]

8. Capobussi, M.; Tettamanti, R.; Marcolin, L.; Piovesan, L.; Bronzin, S.; Gattoni, M.E.; Polloni, I.; Sabatino, G.; Tersalvi, C.A.; Auxilia, F.; et al. Air Pollution Impact on Pregnancy Outcomes in Como, Italy. J. Occup. Environ. Med. 2016, 58, 47-52. [CrossRef] [PubMed]

9. Capolongo, S.; Cocina, G.G.; Gola, M.; Peretti, G.; Pollo, R. Horizontality and verticality in architectures for health. Technè-J. Technol. Archit. Environ. 2019, 17, 152-160. [CrossRef]

10. Gola, M.; Settimo, G.; Capolongo, S. Chemical Pollution in Healing Spaces: The Decalogue of the Best Practices for Adequate Indoor Air Quality in Inpatient Rooms. Int. J. Environ. Res. Public Health 2019, 6, 4388. [CrossRef]

11. Bassi, A.; Ottone, C.; Dell'Ovo, M. Minimum environmental criteria in the architectural project. Trade-off between environmental, economic and social sustainability. Valori E Valutazioni 2019, 22, 35-45.

12. Joseph, A.; Rashid, M. The architecture of safety: Hospital design. Curr. Opin. Crit. Care 2007, 13, 714-719. [CrossRef]

13. Reiling, J.; Hughes, R.G.; Murphy, M.R. Patient Safety and Quality: An Evidence-Based Handbook for Nurses; Hughes, R.G., Ed.; The Impact of Facility Design on Patient Safety; Rockville (MD), Agency for Healthcare Research and Quality (US): Rockville, MD, USA, 2008.

14. Norman, D.A. The Psychology of Everyday Things USA; Basic Books: New York, NY, USA, 1988.

15. Moscato, U.; Borghini, A.; Teleman, A.A. HVAC Management in Health Facilities. In Indoor Air Quality in Healthcare Facilities, 1st ed.; Capolongo, S., Settimo, G., Gola, M., Eds.; Springer Public Health: New York, NY, USA, 2017; pp. 95-106. [CrossRef]

16. Brambilla, A.; Rebecchi, A.; Capolongo, S. Evidence Based Hospital Design. A literature review of the recent publications about the EBD impact of built environment on hospital occupants' and organizational outcomes. Ann Ig. 2019, 31, 165-180. [CrossRef]

17. Bonadonna, L.; de Grazia, M.C.; Capolongo, S.; Casini, B.; Cristina, M.L.; Daniele, G.; D’Alessandro, D.; De Giglio, O.; Di Benedetto, A.; Di Vittorio, G.; et al. Water safety in healthcare facilities. The Vieste Charter. Ann Ig. 2017, 29, 92-100. [PubMed]

18. Gola, M.; Settimo, G.; Capolongo, S. Indoor Air Quality in Inpatient Environments: A Systematic Review on Factors that Influence Chemical Pollution in Inpatient Wards. J. Healthc. Eng. 2019, 2019, 8358306. [CrossRef] [PubMed] 
19. Soggiu, M.E.; Inglessis, M.; Gagliardi, R.V.; Settimo, G.; Marsili, G.; Notardonato, I.; Avino, P. PM10 and PM2.5 qualitative source apportionment using selective wind direction sampling in a port-industrial area in Civitavecchia, Italy. Atmosphere 2020, 11, 94. [CrossRef]

20. Notardonato, I.; Manigrasso, M.; Pierno, L.; Settimo, G.; Protano, C.; Vitali, M.; Mattei, V.; Martellucci, S.; Fiore, C.D.; Boccia, P.; et al. The importance of measuring ultrafine particles in urban air quality monitoring in small cities. Geogr. Pannon. 2019, 23, 347-358. [CrossRef]

21. Settimo, G.; Mudu, P.; Viviano, G. Air pollution: General problems in the area of Gela. Epidemiol. Prev. 2009, $33,37-42$.

22. Bastonini, E.; Verdone, L.; Morrone, S.; Santoni, A.; Settimo, G.; Marsili, G.; La Fortezza, M.; Di Mauro, E.; Caserta, M. Transcriptional modulation of a human monocytic cell line exposed to PM10 from an urban area. Environ. Res. 2011, 111, 765-774. [CrossRef] [PubMed]

23. Buffoli, M.; Rebecchi, A.; Gola, M.; Favotto, A.; Procopio, G.P.; Capolongo, S. Green soap. A calculation model for improving outdoor air quality in urban contexts and evaluating the benefits to the population's health status. In Integrated Evaluation for the Management of Contemporary Cities; Mondini, G., Fattinnanzi, E., Oppio, A., Bottero, M., Stanghellini, S., Eds.; Green Energy and Technology: Cham, Switzerland, 2018; pp. 453-467. [CrossRef]

24. Capasso, L.; Faggioli, A.; Rebecchi, A.; Capolongo, S.; Gaeta, M.; Appolloni, L.; De Martino, A.; D’Alessandro, D. Hygienic and sanitary aspects in urban planning: Contradiction in national and local urban legislation regarding public health. Epidemiol. Prev. 2018, 42, 60-64. [CrossRef] [PubMed]

25. Rebecchi, A.; Buffoli, M.; Dettori, M.; Appolloni, L.; Azara, A.; Castiglia, P.; D’Alessandro, D.; Capolongo, S. Walkable environments and healthy urban moves: Urban context features assessment framework experienced in Milan. Sustainability 2019, 11, 2778. [CrossRef]

26. Coppola, L.; Ripamonti, E.; Cereda, D.; Gelmi, G.; Pirrone, L.; Rebecchi, A. 2015-2018 Regional Prevention Plan of Lombardy (Northern Italy) and sedentary prevention: A cross-sectional strategy to develop evidence-based programmes. Epidemiol. Prev. 2016, 40, 243-248. [CrossRef]

27. Lenzi, A.; Capolongo, S.; Ricciardi, W.; Signorelli, C.; Napier, D.; Rebecchi, A.; Spinato, C. New competences to manage urban health: Health City Manager core curriculum. Acta Biomed. 2020, 91 (Suppl. 3), 21-28. [CrossRef] [PubMed]

28. Capolongo, S.; Buffoli, M.; Mosca, E.I.; Galeone, D.; D’Elia, R.; Rebecchi, A. Public Health Aspects' Assessment Tool for Urban Projects, According to the Urban Health Approach. In Regeneration of the Built Environment from a Circular Economy Perspective; Della Torre, S., Cattaneo, S., Lenzi, C., Zanelli, A., Eds.; Research for Development: Cham, Switzerland, 2020; pp. 325-335. [CrossRef]

29. Leung, M.; Chan, A.H.S. Control and management of hospital indoor air quality. Med. Sci. Monit. 2006, 12, SR17-SR23. [CrossRef]

30. Bessonneau, V.; Mosqueron, L.; Berrubé, A.; Mukensturm, G.; Buffet-Bataillon, S.; Gangneux, J.P.; Thomas, O. VOC contamination in hospital, from stationary sampling of a large panel of compounds, in view of healthcare workers and patients exposure assessment. PLoS ONE 2013, 8, e55535. [CrossRef]

31. Settimo, G. Existing guidelines in indoor air quality: The case study of hospital environments. In Indoor Air Quality in Healthcare Facilities, 1st ed.; Capolongo, S., Settimo, G., Gola, M., Eds.; Springer Public Health: New York, NY, USA, 2017; pp. 13-26. [CrossRef]

32. Qian, H.; Nielsen, P.V.; Li, Y.G.; Hyldgaard, C.E. Dispersion of exhalation pollutants in a two-bed hospital ward with downward ventilation system. Build. Environ. 2008, 43, 344-354. [CrossRef]

33. Harvey, T.E., Jr.; Pati, D. Keeping watch. Design features to aid patient and staff visibility. Health facil. Manag. 2012, 25, 27-31.

34. Mezzoiuso, A.G.; Gola, M.; Rebecchi, A.; Riccò, M.; Capolongo, S.; Buffoli, M.; Tirani, M.; Odone, A.; Signorelli, C. Ambienti confinati e salute: Revisione sistematica della letteratura sui rischi legati all'utilizzo dei seminterrati a scopo abitativo. Acta Biomed. 2017, 88, 375-382. [CrossRef] [PubMed]

35. Settimo, G. Residential indoor air quality: Significant parameters in light of the new trends. Igiene E Sanità Pubbl. 2012, 68, 136-138.

36. ISIAQ (International Society of Indoor Air Quality and Climate). Task Force Report: ISIAQ Review on Indoor Air Quality in Hospitals and other Health Care Facilities; International Society of Indoor Air Quality and Climate: Herndon, VA, USA, 2003; Volume 43. 
37. Gola, M.; Settimo, G.; Capolongo, S. Indoor air in healing environments: Monitoring chemical pollution in inpatient rooms. Facilities 2019, 37, 600-623. [CrossRef]

38. Salonen, H.; Lappalainen, S.; Lahtinen, M.; Knibbs, L.; Morawska, L. Positive impacts of environmental characteristics on health and wellbeing in health-care facilities: A review. In Proceedings of the 10th International Conference on Healthy Buildings, Brisbane, Australia, 8-12 July 2012; Volume 2, pp. 1449-1454.

39. Setola, N.; Borgianni, S. Designing Public Spaces in Hospitals; Taylor and Francis Inc.: London, UK, 2016. [CrossRef]

40. Capolongo, S.; Bellini, E.; Nachiero, D.; Rebecchi, A.; Buffoli, M. Soft qualities in healthcare Method and tools for soft qualities design in hospitals' built environments. Annali Ig. 2014, 26, 391-399. [CrossRef]

41. Rebecchi, A.; Mapelli, A.; Pirola, M.; Capolongo, S. SNAP House. Temporary residential module for refugees in Europe. Technè-J. Technol. Archit. Environ. 2017, 14, 286-295. [CrossRef]

42. Gola, M. Sustainable High Quality Healthcare Facilities. Indoor Air Quality as Health Promoter in Healing Environments. Ph.D. Thesis, Politecnico di Milano, Milan, Italy, 2018.

43. D'Amico, A.; Fara, G.M. The need to develop a multidisciplinary expertise for the microbiological safety of operating theatres. Annali Ig. 2016, 28, 379-380. [CrossRef]

44. Sdino, L.; Zorzi, F.; Rosasco, P.; Magoni, S. The Mass Appraisal Tool: Application of a Pluri-Parametric Model for the Appraisal of Real Properties. In Appraisal: From Theory to Practice, 1st ed.; Stanghellini, S., Morano, P., Bottero, M., Oppio, A., Eds.; Springer Green Energy and Technology: Cham, Switzerland, 2017; pp. $39-52$. [CrossRef]

45. Montagna, M.T.; Cristina, M.L.; De Giglio, O.; Spagnolo, A.M.; Napoli, C.; Cannova, L.; Deriu, M.G.; Delia, S.A.; Giuliano, A.; Guida, M.; et al. Serological and molecular identification of Legionella spp. isolated from water and surrounding air samples in Italian healthcare facilities. Environ. Res. 2016, 146, 47-50. [CrossRef]

46. Ardoino, I.; Zangirolami, F.; Iemmi, D.; Lanzoni, M.; Cargnelutti, M.; Biganzoli, E.; Castaldi, S. Risk factors and epidemiology of Acinetobacter baumannii infections in a university hospital in Northern Italy: A case-control study. Am. J. Infect. Control 2016, 44, 1600-1605. [CrossRef]

47. Azara, A.; Dettori, M.; Castiglia, P.; Piana, A.; Durando, P.; Parodi, V.; Salis, G.; Saderi, L.; Sotgiu, G. Indoor Radon Exposure in Italian Schools. Int. J. Environ. Res. Public Health 2018, 15, 749. [CrossRef]

48. Carducci, A.L.; Fiore, M.; Azara, A.; Bonaccorsi, G.; Bortoletto, M.; Caggiano, G.; Calamusa, A.; De Donno, A.; De Giglio, O.; Dettori, M.; et al. Environment and health: Risk perception and its determinants among Italian university students. Sci. Total Environ. 2019, 691, 1162-1172. [CrossRef] [PubMed]

49. Vassura, I.; Venturini, E.; Bernardi, E.; Passarini, F.; Settimo, G. Assessment of indoor pollution in a school environment through both passive and continuous samplings. Environ. Eng. Manag. J. 2015, 14, 1761-1770.

50. Aversa, P.; Settimo, G.; Gorgoglione, M.; Bucci, E.; Padula, G.; De Marco, A. A case study of indoor air quality in a classroom by comparing passive and continuous monitoring. Environ. Eng. Manag. J. 2019, 18, 2107-2115.

51. Settimo, G.; Bonadonna, L.; Gherardi, M.; di Gregorio, F.; Cecinato, A. The National Indoor Pollution Study Group. Qualità dell'aria negli ambienti sanitari: Strategie di monitoraggio degli inquinanti chimici e biologici. Rapporti ISTISAN 2019, 19/17, 1-55.

52. WHO. Guidelines for Indoor Air Quality: Selected Pollutants, 1st ed.; World Health Organization: Copenhagen, Denmark, 2010.

53. Gola, M.; Mele, A.; Tolino, B.; Capolongo, S. Applications of IAQ Monitoring in International Healthcare Systems. In Indoor Air Quality in Healthcare Facilities, 1st ed.; Capolongo, S., Settimo, G., Gola, M., Eds.; Springer Public Health: New York, NY, USA, 2017; pp. 27-39. [CrossRef]

54. WHO. United Nations Framework Convention on Climate Change. In Climate and Health Country Profile Italy, 1st ed.; World Health Organization: Genoa, Italy, 2018.

55. Dell'Ovo, M.; Frej, E.A.; Oppio, A.; Capolongo, S.; Morais, D.C.; de Almeida, A.T. Multicriteria decision making for healthcare facilities location with visualization based on FITradeoff method. Lecture Notes in Business Information Processing. In Proceedings of the International Conference on Decision Support System Technology, Namur, Belgium, 29-31 May 2017; Volume 282, pp. 32-44. [CrossRef]

56. Dell'Ovo, M.; Capolongo, S.; Oppio, A. Combining spatial analysis with MCDA for the siting of healthcare facilities. Land Use Policy 2018, 76, 634-644. [CrossRef] 
57. Mainini, A.G.; Poli, T.; Paolini, R.; Zinzi, M.; Vercesi, L. Transparent multilayer ETFE panels for building envelope: Thermal transmittance evaluation and assessment of optical and solar performance decay due to soiling. Energy Procedia 2013, 48, 1302-1310. [CrossRef]

58. ASHRAE 170. Ventilation of Health Care Facilities; ASHRAE: New York, NY, USA, 2017.

59. Escombe, A.R.; Oeser, C.C.; Gilman, R.H.; Navincopa, M.; Ticona, E.; Pan, W.; Martínez, C.; Chacaltana, J.; Rodríguez, R.; Moore, D.A.J.; et al. Natural ventilation for the prevention of airborne contagion. PLoS Med. 2007, 4, 309-317. [CrossRef]

60. Hathway, A.; Papakonstantis, I.; Bruce-Konuah, A.; Brevis, W. Experimental and modelling investigations of air exchange and infection transfer due to hinged-door motion in office and hospital settings. Int. J. Vent. 2015, 14, 127-140. [CrossRef]

61. Kalliomaki, P.; Koskela, H.; Saarinen, P.; Tang, J.W.; Klettner, C.; Nicolle, A. Different types of door-opening motions as contributing factors to containment failures in hospital isolation rooms. PLoS ONE 2013, 8, e66663. [CrossRef]

62. Kalliomäki, P.; Saarinen, P.; Tang, J.W.; Koskela, H. Airflow Patterns through Single Hinged and Sliding Doors in Hospital Isolation Rooms. Int. J. Vent. 2015, 14, 111-126. [CrossRef]

63. Tang, J.W.; Noakes, C.J.; Nielsen, P.V.; Eames, I.; Nicolle, A.; Li, Y.; Settles, G.S. Observing and quantifying airflows in the infection control of aerosol- and airborne-transmitted diseases: An overview of approaches. J. Hosp. Infect. 2011, 77, 213-222. [CrossRef]

64. Sehulster, L.M.; Chinn, R.Y.W.; Arduino, M.J.; Carpenter, J.; Donlan, R.; Ashford, D.; Besser, R.; Fields, B.; McNeil, M.M.; Whitney, C.W.; et al. Guidelines for Environmental Infection Control in Health-Care Facilities. Recommendations of CDC and the Healthcare Infection Control Practices Advisory Committee (HICPAC); U.S. Department of Health and Human Services Centers for Disease Control and Prevention (CDC): Atlanta, GA, USA, 2003.

65. UNI EN ISO 16890-1:2017. Filtri D'aria Per Ventilazione Generale-Parte 1: Specifiche Tecniche, Requisiti E Sistema di Classificazione Dell'efficienza Basato sul Particolato (ePM); Ente Italiano di Normazione: Rome, Italy, 2017.

66. DPR 14/01/1997. Structural, Technological and Organizational Minimum Requirements for Health and Sanitary Activities by Public and Private Facilities; Italian Republic President Act: Rome, Italy, 1997.

67. Joppolo, C.M.; Romano, F. HVAC System Design in Health Care Facilities and Control of Aerosol Contaminants: Issues, Tools and Experiments. In Indoor Air Quality in Healthcare Facilities, 1st ed.; Capolongo, S., Settimo, G., Gola, M., Eds.; Springer Public Health: New York, NY, USA, 2017; pp. 83-94. [CrossRef]

68. Oddo, A. The contribution of technology and the forefront role of technical measures in the prevention of infection risk in the healthcare sector. La Med. Lav. 2016, 107, 21-30.

69. Oddo, A. The intervention of the judicial system in order to maximise the prevention of chemical risk in operating theatres and to put personal health and safety first. La Med. Lav. 2016, 107, 5-20.

70. Gray, W.A.; Vittori, G.; Guenther, R.; Vernon, W.; Dilwali, K. Leading the way: Innovative sustainable design guidelines for operating healthy healthcare buildings. In Proceedings of the ISIAQ-10th International Conference on Healthy Buildings, Curran Associates, Red Hook, NY, USA, 12 July 2012; pp. 1212-1217.

71. Oberti, I. Environmentally Friendly and Low-Emissivity Construction Materials and Furniture Existing guidelines in indoor air quality: The case study of hospital environments. In Indoor Air Quality in Healthcare Facilities, 1st ed.; Capolongo, S., Settimo, G., Gola, M., Eds.; Springer Public Health: New York, NY, USA, 2017; pp. 73-81. [CrossRef]

72. ASHRAE 62-1. Ventilation for Acceptable Indoor Air Quality; ASHRAE: New York, NY, USA, 2019.

73. UNI 10339:1995. Impianti aeraulici ai fini di benessere. In Generalità, Classificazione E Requisiti. Regole per la Richiesta D'offerta, L'offerta, L'ordine E la Fornitura; Ente Italiano di Normazione: Rome, Italy, 1995.

74. Hsu, Y.C.; Chao, H.R.; Shih, S.I. Human exposure to airborne aldehydes in Chinese medicine clinics during moxibustion therapy and its impact on risks to health. J. Environ. Sci. Health A 2015, 50, 260-271. [CrossRef]

75. Lu, C.Y.; Kang, S.Y.; Liu, S.H.; Mai, C.W.; Tseng, C.H. Controlling Indoor Air Pollution from Moxibustion. Int. J. Environ. Res. Public Health 2006, 13, 612. [CrossRef]

76. Śmiełowska, M.; Marć, M.; Zabiegała, B. Indoor air quality in public utility environments-A review. Environ. Sci. Pollut. Res. 2017, 24, 11166-11176. [CrossRef]

77. Cantagalli, D. I prodotti chimici in ambito ospedaliero. In Caratteristiche, Performance, Rischi, Risultati. Quali Prodotti Chimici a Seconda degli Ambiti di Intervento; Politecnico di Milano: Milan, Italy, 2017. 
78. Bello, A.; Quinn, M.M.; Perry, M.J.; Milton, D.K. Quantitative assessment of airborne exposures generated during common cleaning tasks: A pilot study. Environ. Health 2010, 9, 76. [CrossRef]

79. Masia, M.D.; Solinas, G.; Piana, A.; Dettori, M.; Sotgiu, G.; Castiglia, P. Smoking habit and behaviour among health professionals. Annali Ig. 2006, 18, 261-269.

80. Giofrè, F. Materiali, arredi e attrezzature in Sala operatoria e Terapia intensiva. In Dalla Pratica Medica al Design per la Prevenzione Delle Infezioni, 1st ed.; Ciraolo, F., Giofrè, F., Eds.; Maggioli Editore: Santarcangelo di Romagna, Italy, 2013; pp. 151-172.

81. Settimo, G.; Gola, M.; Mannoni, V.; De Felice, M.; Padula, G.; Mele, A.; Tolino, B.; Capolongo, S. Assessment of Indoor Air Quality in Inpatient Wards. In Indoor Air Quality in Healthcare Facilities, 1st ed.; Capolongo, S., Settimo, G., Gola, M., Eds.; Springer Public Health: New York, NY, USA, 2017; pp. 107-118. [CrossRef]

82. Zuraimi, M.S.; T, K.W.; Chew, F.T.; Ooi, P.L. The effects of ventilation strategies of child care centers on indoor air quality and respiratory health of children in Singapore. Indoor Air 2007, 17, 317-327. [CrossRef]

83. Brambilla, A.; Buffoli, M.; Capolongo, S. Measuring hospital qualities. A preliminary investigation on Health Impact Assessment possibilities for evaluating complex buildings. Acta Biomed. Atenei Parm. 2019, 90, 54-63. [CrossRef]

84. Brambilla, A.; Capolongo, S. Healthy and sustainable hospital evaluation-A review of POE tools for hospital assessment in an evidence-Based design framework. Buildings 2019, 9, 76. [CrossRef]

85. Borghini, A.; Poscia, A.; Bosello, S.; Teleman, A.A.; Bocci, M.; Iodice, L.; Ferraccioli, G.; La Milìa, D.; Moscato, U. Environmental pollution by benzene and PM10 and clinical manifestations of systemic sclerosis: A correlation study. Int. J. Environ. Res. Public Health 2017, 14, 1297. [CrossRef] [PubMed]

86. Bianchi, C.L.; Colombo, E.; Gatto, S.; Stucchi, M.; Cerrato, G.; Morandi, S.; Capucci, V. Photocatalytic degradation of dyes in water with micro-sized $\mathrm{TiO}_{2}$ as powder or coated on porcelain-gres tiles. J. Photochem. Photobiol. A 2014, 280, 27-31. [CrossRef]

87. De Oliveira, A.C.; Damasceno, Q.S. Surfaces of the hospital environment as possible deposits of resistant bacteria: A review. Rev Esc Enferm USP 2010, 44, 1112-1117. [CrossRef]

88. Dore, S.; Sotgiu, G.; Piana, A.; Are, B.M.; Arru, B.; Puddu, A.; Piredda, C.; Dettori, M.; Palmieri, A.; Porcu, A.; et al. Microbial contamination of surfaces in the departments of Medicine and Surgery: Single center prevalence study in Sassari (Italy). Recenti Progress. Med. 2016, 107, 50-54. [CrossRef]

89. Pati, D.; Park, C.-S.; Augenbroe, G. Facility maintenance performance perspective to target strategic organizational objectives. J. Perform. Constr. Facil. 2010, 24, 180-187. [CrossRef]

90. Mauri, M. The future of the hospital and the structures of the NHS. Technè-J. Technol. Archit. Environ. 2015, 9, 27-34. [CrossRef]

91. Tirler, W.; Settimo, G. Incense, sparklers and cigarettes are significant contributors to indoor benzene and particle levels. Annali dell'Istituto Super. Sanit. 2015, 51, 28-33. [CrossRef]

92. Capolongo, S.; Rebecchi, A.; Buffoli, M.; Appolloni, L.; Signorelli, C.; Fara, G.M.; D'Alessandro, D. COVID-19 and Cities: From Urban Health strategies to the pandemic challenge. A Decalogue of Public Health opportunities. Acta Biomed. 2020, 91, 13-22. [CrossRef] [PubMed]

(C) 2020 by the authors. Licensee MDPI, Basel, Switzerland. This article is an open access article distributed under the terms and conditions of the Creative Commons Attribution (CC BY) license (http://creativecommons.org/licenses/by/4.0/). 